This document is confidential and is proprietary to the American Chemical Society and its authors. Do not copy or disclose without written permission. If you have received this item in error, notify the sender and delete all copies.

\title{
Long-Lived, Strongly Emissive and Highly Reducing Excited States in Mo(0) Complexes with Chelating Isocyanides
}

\begin{tabular}{|c|c|}
\hline Journal: & Journal of the American Chemical Society \\
\hline Manuscript ID & ja-2019-07373p.R1 \\
\hline Manuscript Type: & Article \\
\hline $\begin{array}{r}\text { Date Submitted by the } \\
\text { Author: }\end{array}$ & 17-Aug-2019 \\
\hline Complete List of Authors: & $\begin{array}{l}\text { Herr, Patrick; Universitat Basel, Department of Chemistry } \\
\text { Glaser, Felix; Universitat Basel, Department of Chemistry } \\
\text { Büldt, Laura; Universitat Basel, Department of Chemistry } \\
\text { Larsen, Christopher; Universitat Basel, Department of Chemistry } \\
\text { Wenger, Oliver; Universitat Basel, Department of Chemistry }\end{array}$ \\
\hline
\end{tabular}

\section{SCHOLARONE \\ Manuscripts}




\title{
Long-Lived, Strongly Emissive and Highly Reducing Excited States in $\mathrm{Mo}(\mathrm{o})$ Complexes with Chelating Isocyanides
}

\author{
Patrick Herr, ${ }^{\dagger}$ Felix Glaser, ${ }^{\dagger}$ Laura A. Büldt, ${ }^{\dagger}$ Christopher B. Larsen, and Oliver S. Wenger ${ }^{*}$ \\ Department of Chemistry, University of Basel, St. Johanns-Ring 19, 4056 Basel, Switzerland
}

\begin{abstract}
Newly discovered tris(diisocyanide)molybdenum(o) complexes are Earth-abundant isoelectronic analogs of the well-known class of $\left[\mathrm{Ru}(\alpha \text {-diimine })_{3}\right]^{2+}$ compounds with long-lived ${ }^{3} \mathrm{MLCT}$ (metal-to-ligand charge transfer) excited states that lead to rich photophysics and photochemistry. Depending on ligand design, luminescence quantum yields up to 0.20 and microsecond excited state lifetimes are achieved in solution at room temperature, both significantly better than for $\left[\mathrm{Ru}\left(2,2^{\prime} \text {-bipyridine }\right)_{3}\right]^{2+}$. The excited $\mathrm{Mo}(\mathrm{o})$ complexes can induce chemical reactions that are thermodynamically too demanding for common precious metal based photosensitizers, including the widely employed $f a c$-[ $\operatorname{Ir}(2 \text {-phenylpyridine })_{3}$ ] complex, as demonstrated on a series of light-driven aryl-aryl coupling reactions. The most robust Mo(o) complex exhibits stable photoluminescence and remains photoactive after continuous irradiation exceeding two months. Our comprehensive optical spectroscopic and photochemical study shows that Mo(o) complexes with diisocyanide chelate ligands constitute a new family of luminophores and photosensitizers, which is complementary to precious metal based $4 \mathrm{~d}^{6}$ and $5 \mathrm{~d}^{6}$ complexes and represents an alternative to non-emissive Fe(II) compounds. This is relevant in the greater context of sustainable photophysics and photochemistry, as well as for possible applications in lighting, sensing, and catalysis.
\end{abstract}

\section{INTRODUCTION}

The long-lived luminescent metal-to-ligand charge transfer (MLCT) excited states of complexes with precious $d^{6}$ metals such as $\mathrm{Ru}(\mathrm{II}), \operatorname{Ir}(\mathrm{III})$, Os(II), or $\operatorname{Re}(\mathrm{I})$ form the basis for many photophysical and photochemical applications, for example in luminescent devices, ${ }^{1}$ sensing, ${ }^{2-3}$ solar energy conversion, ${ }^{4}$ and photoredox catalysis. ${ }^{5}$ There is a long-standing interest in obtaining complexes with similarly favorable electronic structures made from cheaper first-row transition metal elements. ${ }^{6-8}$ $\mathrm{Fe}(\mathrm{II})$ is an obvious and much explored target, ${ }^{9-15}$ because iron is the most abundant and cheapest transition metal in Earth's crust. However, such $3 \mathrm{~d}^{6}$ complexes have energetically low-lying metal-centered (MC) excited states that deactivate the MLCT states very efficiently. ${ }^{16-18}$ Different concepts have been explored to lengthen ${ }^{3} \mathrm{MLCT}$ lifetimes in $\mathrm{Fe}$ (II) complexes, including the optimization of metal coordination geometries, ${ }^{19-21}$ the use of push-pull ligand environments, ${ }^{22-23}$ and the enhancement of ligand fields with $\mathrm{N}$-heterocyclic ${ }^{24-27}$ or mesoionic carbenes. ${ }^{28}$ Recently, these efforts culminated in the discovery of two $\mathrm{Fe}(\mathrm{III})$ complexes that luminesce from a ligand-to-metal charge transfer (LMCT) excited state ${ }^{29-30}$ and an $\mathrm{Fe}(\mathrm{II})$ complex with a ${ }^{3}$ MLCT lifetime of 528 ps in solution at room temperature. ${ }^{31}$

Building on early studies of group $6 \mathrm{~d}^{6}$ metal complexes with isocyanide ligands $32-33$ and recent reports of luminescent $\mathrm{W}(\mathrm{o})$ complexes with monodentate isocyanides,34-35 we recently discovered that chelating diisocyanide ligands give access to $\operatorname{Cr}(\mathrm{o})$ and $\operatorname{Mo}(\mathrm{o})$ complexes with emissive ${ }^{3}$ MLCT excited states. ${ }^{6}$ The $\mathrm{Cr}(\mathrm{o})$ complex exhibited an excited-state lifetime of $2.2 \mathrm{~ns}$ and a luminescence quantum yield of ca. $10^{-5}$ in THF solution at room temperature, 37 whilst the Mo(o) complex had a 3MLCT lifetime of $166 \mathrm{~ns}$ and a quantum yield of 0.023 in toluene. ${ }^{8}$ Herein, we report how improved ligand design can enhance both of these properties in Mo(o) complexes by an order of magnitude, and it becomes evident that the initially communicated single example is not merely an academic curiosity, but instead tris(diisocyanide)molybdenum(o) complexes represent a new family of robust $4 \mathrm{~d}^{6}$ complexes with very favorable photophysical properties. Moreover, we demonstrate that excitation of these complexes can induce chemical reactions that are thermodynamically too challenging for typical precious metal-based photosensitizers, such as the well-known $f a c$ - $\left[\operatorname{Ir}(\mathrm{ppy})_{3}\right]$ complex. For this purpose, we investigated base-promoted homolytic aromatic substitution (BHAS) reactions, 39 which were performed in an intramolecular fashion on a series of substrates specifically designed to elucidate the catalytic properties of the Mo(o) complexes.

Our study complements ongoing research on photoactive complexes with other Earth-abundant metal elements such as $\mathrm{Fe}^{,}{ }^{9-15} \mathrm{Cu},{ }^{40-50} \mathrm{Cr},{ }^{51-54} \mathrm{Co},{ }^{55} \mathrm{Ni},{ }^{5-58} \mathrm{Zr},{ }^{59-60}$ $\mathrm{W},{ }^{34-35},{ }^{61-63}$ and $\mathrm{Ce},{ }^{64}$ as well as current research on new metal-free organic photosensitizers. ${ }^{65-69}$ 
Scheme 1. Molecular structures of $(a)\left[\mathrm{Mo}\left(\mathrm{L}^{\mathrm{Me}}\right)_{3}\right]$ and (b) $\left[\mathrm{Mo}\left(\mathrm{L}^{\mathrm{tBu}}\right)_{3}\right]$.
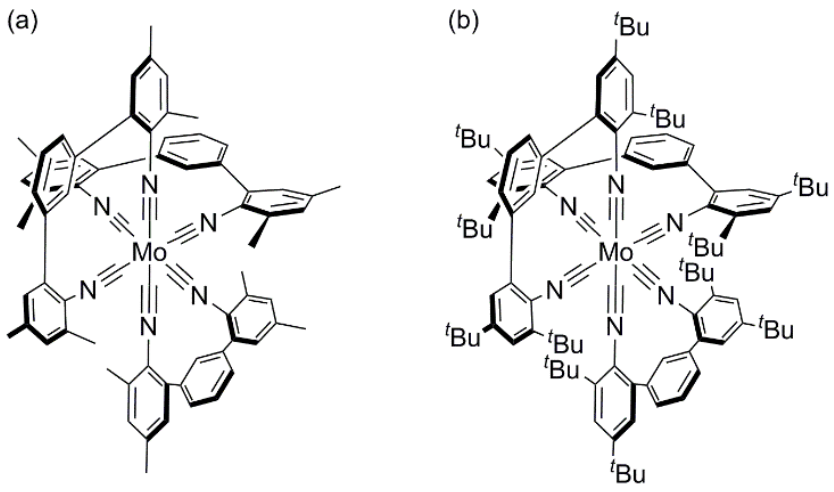

\section{RESULTS AND DISCUSSION}

\section{Synthesis and infrared spectroscopy}

Monodentate isocyanide ligands play an important role in organometallic chemistry as alternatives to $\mathrm{CO}$ that can be further functionalized, $7^{0-71}$ and one attractive option is to create polydentate chelating isocyanides. ${ }^{72-80}$ In our initial communication, we reported that a $m$-terphenyl backbone is useful to obtain a diisocyanide ligand that binds $\mathrm{Mo}(\mathrm{o})$ in chelating fashion, giving access to a homoleptic complex (Scheme 1a, $\left[\mathrm{Mo}\left(\mathrm{L}^{\mathrm{Me}}\right)_{3}\right]$ ) that is structurally and electronically similar to $\left[\mathrm{Ru}(\mathrm{bpy})_{3}\right]^{2+}$ (bpy $=2,2$-bipyridine). ${ }^{38}$ Sterically demanding groups in $\alpha$ position to the ligating isocyanides usually stabilize lowvalent transition metal species, rendering them less susceptible to electrophilic attack. ${ }^{71},{ }^{81}$ We therefore reasoned that bulkier tert-butyl (rather than methyl) substituents could minimize interactions between the $\operatorname{Mo}(\mathrm{o})$ center and the solvent, as well as rigidifying the complex, potentially leading to decreased nonradiative ${ }_{3}$ MLCT deactivation. In the resulting new $\left[\mathrm{Mo}\left(\mathrm{L}^{t \mathrm{Bu}}\right)_{3}\right]$ complex (Scheme $1 \mathrm{~b}$ ), this is indeed the case, as our detailed comparative photophysical study with $\left[\mathrm{Mo}\left(\mathrm{L}^{\mathrm{Me}}\right)_{3}\right]$ will show. We had previously used $\mathrm{L}^{t \mathrm{Bu}}$ to obtain a luminescent $\mathrm{Cr}(\mathrm{o})$ complex,37 and the synthesis of $\mathrm{L}^{\mathrm{Me}}$ was reported in our initial $\mathrm{Mo}(\mathrm{o})$ communication. ${ }^{38}$ The new $\left[\mathrm{Mo}\left(\mathrm{L}^{t \mathrm{Bu}}\right)_{3}\right]$ complex was prepared by stirring a suspension of $\left[\mathrm{MoCl}_{2}(\mathrm{THF})_{4}\right]$ and 3 equivalents of $\mathrm{L}^{t \mathrm{Bu}}$ in THF over $\mathrm{Na} / \mathrm{Hg}$ (see Supporting Information page S2 for details). The complex was isolated as a red powder that can be handled under air.

The $\mathrm{C} \equiv \mathrm{N}$ stretch frequencies in the free $\mathrm{L}^{\mathrm{Me}}$ and $\mathrm{L}^{t \mathrm{Bu}}$ ligands are 2113 and $2112 \mathrm{~cm}^{-1}$ (Figure $\mathrm{S}_{4}$ ), respectively. In the $\left[\mathrm{Mo}\left(\mathrm{L}^{\mathrm{Me}}\right)_{3}\right]$ and $\left[\mathrm{Mo}\left(\mathrm{L}^{t \mathrm{Bu}}\right)_{3}\right]$ complexes, the $\mathrm{C} \equiv \mathrm{N}$ vibrations are broad and intense, and their maxima are shifted to 1939 and $1951 \mathrm{~cm}^{-1}$, respectively, due to $\pi$ backbonding. ${ }^{82}$

\section{Electrochemistry}

In cyclic voltammetry, oxidation of $\mathrm{Mo}(\mathrm{o})$ to $\mathrm{Mo}(\mathrm{I})$ in deaerated THF with o.1 $\mathrm{M} \mathrm{TBAPF}_{6}$ results in quasi-reversible waves from which potentials of -0.02 and $-0.08 \mathrm{~V}$ vs SCE can be determined for $\left[\mathrm{Mo}\left(\mathrm{L}^{\mathrm{Me}}\right)_{3}\right]$ and $\left[\mathrm{Mo}\left(\mathrm{L}^{t \mathrm{Bu}}\right)_{3}\right]$, respectively (Figure 1 ). These potentials are shifted anodically by $0.2-0.3 \mathrm{~V}$ relative to those for previously reported $\mathrm{Mo}(\mathrm{o})$ complexes with monodentate arylisocyanides (Table 1 ). ${ }^{83}$

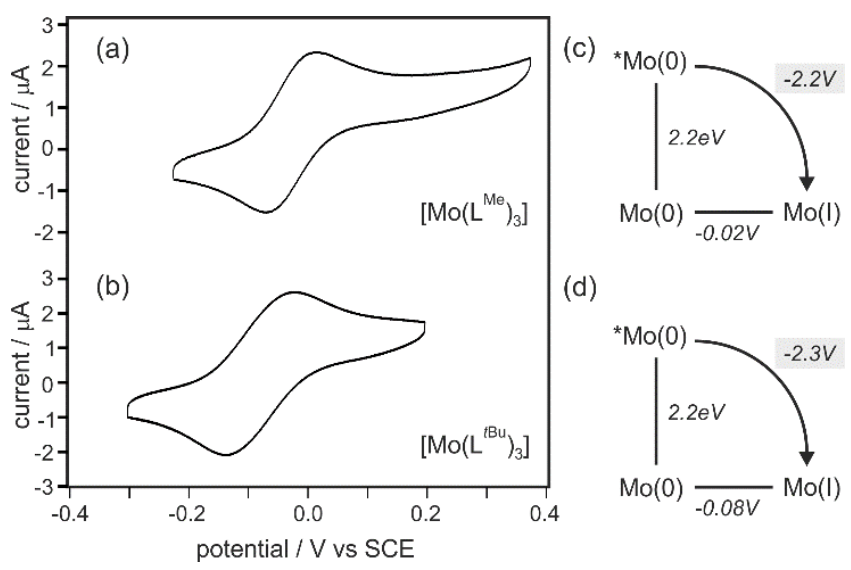

Figure 1. Cyclic voltammograms of (a) $\left[\mathrm{Mo}\left(\mathrm{L}^{\mathrm{Me}}\right)_{3}\right]$ and (b) $\left[\mathrm{Mo}\left(\mathrm{L}^{t \mathrm{Bu}}\right)_{3}\right]$ recorded in de-aerated THF with o.1 M TBAPF 6 at $20{ }^{\circ} \mathrm{C}$. The potential scan rates were 0.1 and $0.2 \mathrm{~V} / \mathrm{s}$, respectively. The differences in anodic and cathodic peak currents are $86 \mathrm{mV}$ (a) and $116 \mathrm{mV}$ (b). (c, d) Latimer diagrams for $\left[\mathrm{Mo}\left(\mathrm{L}^{\mathrm{Me}}\right)_{3}\right]$ and $\left[\mathrm{Mo}\left(\mathrm{L}^{t \mathrm{Bu}}\right)_{3}\right]$, based on an energy of $2.2 \mathrm{eV}$ for the emissive ${ }^{3}$ MLCT excited state (Figure $\mathrm{S} 7 \mathrm{~b}$ ).

Table 1. Electrochemical potentials (in Vvs SCE) in the electronic ground state and in the long-lived 3MLCT excited state.

\begin{tabular}{|c|c|c|}
\hline & $E^{\mathrm{o}}\left(\mathrm{M}^{+} / \mathrm{M}^{\mathrm{o}}\right)$ & $E^{\mathrm{o}}\left(\mathrm{M}^{+} /{ }^{*} \mathrm{M}^{\mathrm{o}}\right)$ \\
\hline$\left[\mathrm{Mo}\left(\mathrm{L}^{t \mathrm{Bu}}\right)_{3}\right]^{a}$ & -0.08 & -2.3 \\
\hline$\left[\mathrm{Mo}\left(\mathrm{L}^{\mathrm{Me}}\right)_{3}\right]^{a, b}$ & -0.02 & -2.2 \\
\hline$\left[\mathrm{Mo}\left(\mathrm{CN}-\mathrm{C}_{6} \mathrm{H}_{5}\right)_{6}\right]^{c}$ & -0.24 & \\
\hline$\left[\mathrm{Mo}\left(\mathrm{CN}-2,6-i \mathrm{Pr} \mathrm{C}_{6} \mathrm{H}_{5}\right)_{6}\right]^{c}$ & -0.32 & \\
\hline$f a c-\left[\operatorname{Ir}(\mathrm{ppy})_{3}\right]^{d}$ & 0.77 & -1.7 \\
\hline
\end{tabular}

${ }^{a}$ This work, measured in THF with o.1 $\mathrm{M} \mathrm{TBAPF}_{6}$ (Figure 1). ${ }^{b}$ From ref. 38 , measured in THF with o.1 $\mathrm{M} \mathrm{TBAPF}_{6}{ }^{c}$ From ref. 83, measured in THF with o.1 $\mathrm{M} \mathrm{TBAPF}_{6}$ versus $\mathrm{Ag} / \mathrm{AgCl} .^{d}$ From ref. 84 .

In principle, this shift could be either due to stabilization of the $\mathrm{Mo}(\mathrm{o})$ state or destabilization of the $\mathrm{Mo}(\mathrm{I})$ form in the chelate complexes. ${ }^{85}$ It seems likely that the latter effect is dominant, because the bite angle of the chelating $\mathrm{L}^{\mathrm{Me}}$ and $\mathrm{L}^{t \mathrm{Bu}}$ ligands is expected to become less favorable with increasing oxidation state due to decreasing Mo-C bond distances. Sweeps over greater potential ranges than those in Figure 1 produce lower quality voltammograms, and ligand reduction was undetectable. However, the observable $\operatorname{Mo}(\mathrm{o} / \mathrm{I})$ redox wave is the most important one, because it is directly relevant for the photochemistry of $\left[\mathrm{Mo}\left(\mathrm{L}^{\mathrm{Me}}\right)_{3}\right]$ and $\left[\mathrm{Mo}\left(\mathrm{L}^{\mathrm{tBu}}\right)_{3}\right]$ presented below. 
Table 2. 3MLCT excited state lifetimes $(\tau)$ and luminescence quantum yields $(\phi)$ in de-aerated solvents at $20^{\circ} \mathrm{C}$.

\begin{tabular}{|c|c|c|c|c|c|c|c|c|c|}
\hline & \multicolumn{3}{|c|}{$n$-hexane } & \multicolumn{3}{c|}{ toluene } & \multicolumn{3}{c|}{ THF } \\
\hline & $\tau_{1}[\mathrm{~ns}]$ & $\tau_{2}[\mathrm{~ns}]$ & $\phi$ & $\tau_{1}[\mathrm{~ns}]$ & $\tau_{2}[\mathrm{~ns}]$ & $\phi$ & $\tau_{1}[\mathrm{~ns}]$ & $\tau_{2}[\mathrm{~ns}]$ & $\phi$ \\
\hline$\left[\mathrm{Mo}\left(\mathrm{L}^{\mathrm{tBu}}\right)_{3}\right]^{a}$ & $1040(76 \%)$ & $2370(24 \%)$ & 0.190 & $1110\left(85^{2}\right)$ & $2330(15 \%)$ & 0.203 & $610(73 \%)$ & $1610(27 \%)$ & 0.058 \\
\hline$\left[\mathrm{Mo}\left(\mathrm{L}^{\mathrm{Me}}\right)_{3}\right]^{b}$ & $225(100 \%)$ & - & 0.045 & $166(100 \%)$ & - & 0.023 & $74(100 \%)$ & - & 0.006 \\
\hline
\end{tabular}

${ }^{a}$ This work, extracted from the data in Figure Sio; determined using $\left[\mathrm{Ru}(\mathrm{bpy})_{3}\right]^{2+}$ in aerated $\mathrm{CH}_{3} \mathrm{CN}$ as standard $(\phi=0.018)^{86} b$ From ref. 38.

\section{UV-Vis absorption, luminescence, and transient absorption spectroscopy}

The UV-Vis spectra of $\left[\mathrm{Mo}\left(\mathrm{L}^{\mathrm{Me}}\right)_{3}\right]$ and $\left[\mathrm{Mo}\left(\mathrm{L}^{\mathrm{tBu}}\right)_{3}\right]$ exhibit MLCT absorptions between 350 and $550 \mathrm{~nm}$ (Figure 2a/b), which cause the orange-red color of these complexes. Ligand-based $\pi-\pi^{*}$ transitions appear at shorter wavelengths, and thus the overall spectra are reminiscent of that of isoelectronic $\left[\mathrm{Ru}(\mathrm{bpy})_{3}\right]^{2+}{ }^{26}$ However, the MLCT absorptions in $\left[\mathrm{Mo}\left(\mathrm{L}^{\mathrm{Me}}\right)_{3}\right]$ and $\left[\mathrm{Mo}\left(\mathrm{L}^{\mathrm{tBu}}\right)_{3}\right]$ are broader and have higher extinction coefficients by factors of about 1.5 to 2.0 , respectively.
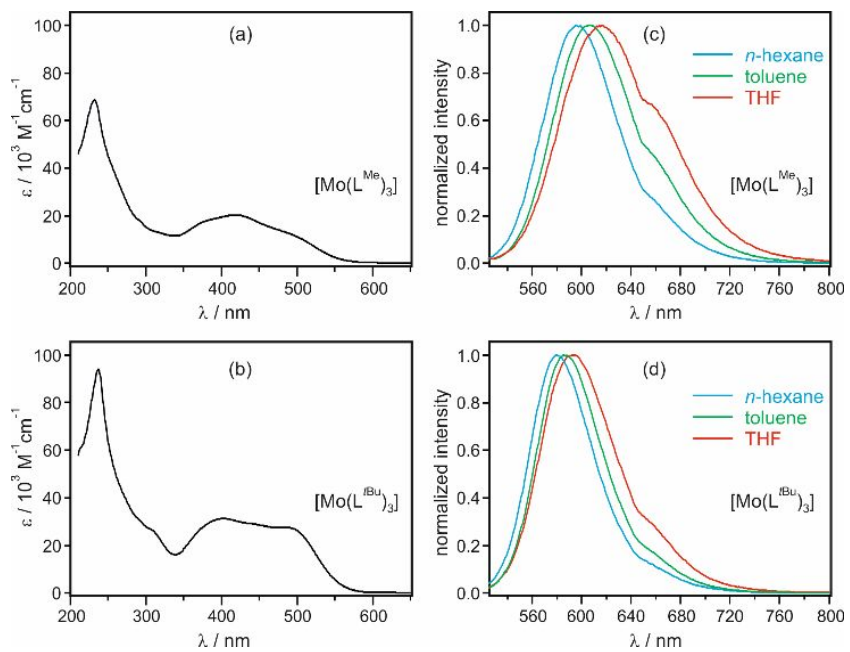

Figure 2. UV-Vis absorption spectra of (a) $\left[\mathrm{Mo}\left(\mathrm{L}^{\mathrm{Me}}\right)_{3}\right]$ and (b) $\left[\mathrm{Mo}\left(\mathrm{L}^{\mathrm{tBu}}\right)_{3}\right]$ in THF at $2 \mathrm{O}^{\circ} \mathrm{C}$. Normalized photoluminescence spectra of $\left(\right.$ c) $\left[\mathrm{Mo}\left(\mathrm{L}^{\mathrm{Me}}\right)_{3}\right]$ and $(\mathrm{d})\left[\mathrm{Mo}\left(\mathrm{L}^{t \mathrm{Bu}}\right)_{3}\right]$ in de-aerated solvents at $20^{\circ} \mathrm{C}$. Excitation occurred at $500 \mathrm{~nm}$.

Upon excitation at $500 \mathrm{~nm}$, both $\mathrm{Mo}(\mathrm{o})$ complexes luminesce in de-aerated solution at room temperature (Figure 2c/d). The emission is broad and unstructured, and there is a sizeable red-shift of the emission band maximum when increasing the solvent polarity from $n$-hexane to toluene and THF $\left(540 \mathrm{~cm}^{-1}\right.$ in total for $\left[\mathrm{Mo}\left(\mathrm{L}^{\mathrm{Me}}\right)_{3}\right], 410 \mathrm{~cm}^{-1}$ for $\left.\left[\mathrm{Mo}\left(\mathrm{L}^{\mathrm{Bu}}\right)_{3}\right]\right)$. These observations are compatible with MLCT emission, in analogy to $\left[\mathrm{Ru}(\mathrm{bpy})_{3}\right]^{2+}$. A key finding is that the luminescence quantum yield $(\phi)$ of the $\left[\mathrm{Mo}\left(\mathrm{L}^{\mathrm{tBu}}\right)_{3}\right]$ complex is much higher than that of $\left[\mathrm{Mo}\left(\mathrm{L}^{\mathrm{Me}}\right)_{3}\right]$ in all investigated solvents. For example, in de-aerated toluene at $20{ }^{\circ} \mathrm{C}$ the complex with the more sterically demanding tert-butyl substituted diisocyanide ligand exhibits $\phi=0.203$ whereas the complex with the methyl- substituents only has $\phi=0.023$ (Table 2). This shows that the aforementioned design principle, according to which better shielding of the metal center from the chemical environment and enhanced complex rigidity should lead to improved photophysical properties, is indeed successful. $\left[\mathrm{Ru}(\mathrm{bpy})_{3}\right]^{2+}$ has a luminescence quantum yield of 0.095 under optimized conditions in de-aerated $\mathrm{CH}_{3} \mathrm{CN}$, more than a factor of 2 lower than $\left.\left[\mathrm{Mo}\left(\mathrm{L}^{\mathrm{tBu}}\right)_{3}\right]\right]^{86}$ Such strong luminescence is remarkable for a d $\mathrm{d}^{6}$ MLCT emitter made from an Earth-abundant transition metal and compares very favorably to most $\mathrm{Cu}(\mathrm{I})$ diimine complexes. $43,87-89$ The latter represent an extremely well investigated class of compounds for which similar luminescence quantum yields required many optimization attempts.
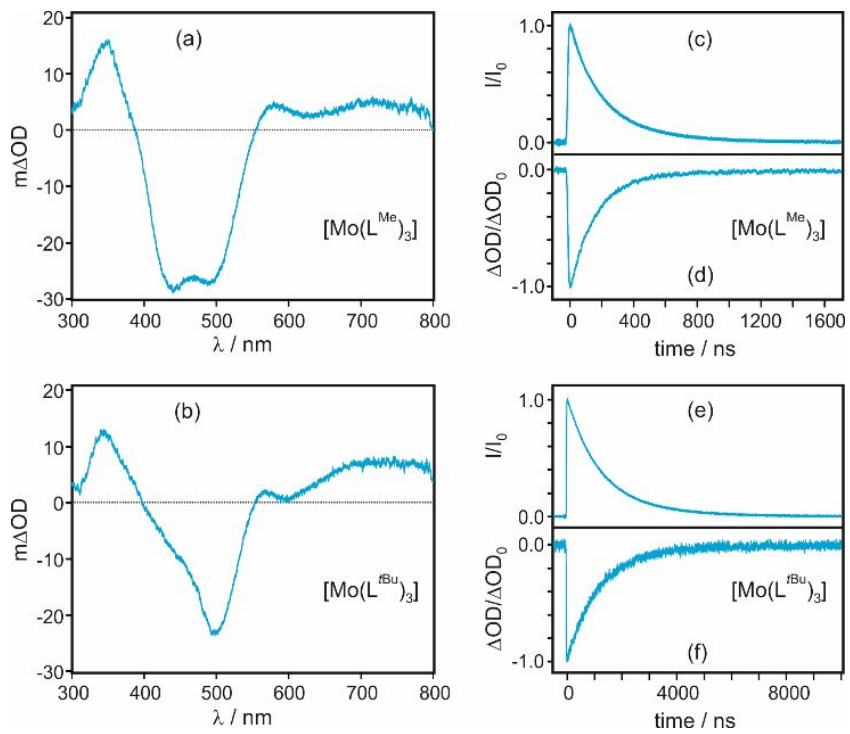

Figure 3. Transient absorption spectra measured after excitation of $10^{-5} \mathrm{M}$ solutions of (a) $\left[\mathrm{Mo}\left(\mathrm{L}^{\mathrm{Me}}\right)_{3}\right]$ and (b) $\left[\mathrm{Mo}\left(\mathrm{L}^{\mathrm{tBu}}\right)_{3}\right]$ in de-aerated toluene at $532 \mathrm{~nm}$ with laser pulses of $\sim 10$ ns duration. The signals were time-integrated over 200 ns immediately after excitation. Luminescence decays (c, e) recorded from these solutions at $615 \mathrm{~nm}$ and recoveries of the MLCT bleaches (d, f) at $485 \mathrm{~nm}$. See Figures S8/Sio for analogous data recorded in other solvents.

Time-resolved luminescence and transient UV/Vis absorption spectroscopy were used to explore the decay characteristics of the emissive excited states and to confirm their MLCT nature. The transient absorption spectra in Figure $3 \mathrm{a} / \mathrm{b}$ were averaged over a period of $200 \mathrm{~ns}$ 
immediately after excitation at $532 \mathrm{~nm}$ with laser pulses of ca. 10 ns duration. In both cases a negative signal (groundstate bleach) is detected near $500 \mathrm{~nm}$, coincident with the lowest-energy ${ }^{1}$ MLCT absorption bands in Figure $2 \mathrm{a} / \mathrm{b}$. Additionally, excited-state absorption bands near $345 \mathrm{~nm}$ are observed for both complexes, reminiscent of the absorption bands near $370 \mathrm{~nm}$ for 3MLCT-excited $\left[\mathrm{Ru}(\mathrm{bpy})_{3}\right]^{2+}$, which are caused by $\pi-\pi^{*}$ transitions on the transiently reduced bpy ligand. $9^{\circ}$ Such short-wavelength excited-state absorption bands combined with groundstate ${ }^{1}$ MLCT bleaches are in fact diagnostic features of MLCT excited states in photoactive $\mathrm{Ru}(\mathrm{II})$ and $\mathrm{Fe}(\mathrm{II})$ complexes. 22,31

As expected, the MLCT luminescence at 595/615 nm and the MLCT bleach at $485 \mathrm{~nm}$ exhibit the same decay for a given complex (Figure $3 \mathrm{c} / \mathrm{d}$, Figure $3 \mathrm{e} / \mathrm{f}$ ), confirming that the same excited state is monitored by emission and transient absorption spectroscopies. However, the MLCT lifetimes $(\tau)$ extractable from these data sets are markedly different for $\left[\mathrm{Mo}\left(\mathrm{L}^{t \mathrm{Bu}}\right)_{3}\right]$ and $\left[\mathrm{Mo}\left(\mathrm{L}^{\mathrm{Me}}\right)_{3}\right]$ in all investigated solvents (Figure S1o). For instance, in de-aerated toluene at $20{ }^{\circ} \mathrm{C}, \tau=166$ ns for $\left[\mathrm{Mo}\left(\mathrm{L}^{\mathrm{Me}}\right)_{3}\right]$, whilst for the $\left[\mathrm{Mo}\left(\mathrm{L}^{t \mathrm{Bu}}\right)_{3}\right]$ complex a bi-exponential decay with $\tau_{1}=1110 \mathrm{~ns}(85 \%)$ and $\tau_{2}=2330 \mathrm{~ns}(15 \%)$ is observed (Table 2 ). Thus, the factorof-10 increase in luminescence quantum yield when going from $\left[\mathrm{Mo}\left(\mathrm{L}^{\mathrm{Me}}\right)_{3}\right]$ to $\left[\mathrm{Mo}\left(\mathrm{L}^{t \mathrm{Bu}}\right)_{3}\right]$ (see above) is accompanied by an equivalent increase in excited-state lifetime, compatible with the view that the rate for radiative decay from the emissive MLCT states is similar in both complexes whereas the rate for non-radiative decay is decreased by an order of magnitude in $\left[\mathrm{Mo}\left(\mathrm{L}^{t \mathrm{Bu}}\right)_{3}\right]$. This is additional confirmation for the success of the design concept outlined in the introduction, and it is evident that the bulkier tertbutyl substituents lead to much improved photophysical properties relative to the methyl-substituents.

In all investigated solvents, the luminescence decays and MLCT bleach recoveries are consistently monoexponential for $\left[\mathrm{Mo}\left(\mathrm{L}^{\mathrm{Me}}\right)_{3}\right]$, whilst for $\left[\mathrm{Mo}\left(\mathrm{L}^{t \mathrm{Bu}}\right)_{3}\right]$ biexponential kinetics were observed in all experiments. The bi-exponential decays are tentatively attributed to the presence of different conformers in the latter. In our previously published crystal structure of $\left[\mathrm{Cr}\left(\mathrm{L}^{t \mathrm{Bu}}\right)_{3}\right]$ the three $\mathrm{L}^{t \mathrm{Bu}}$ ligands are not equivalent, 37 and interconversion between different conformations seems to be sterically hindered by the tert-butyl substituents. In $\left[\mathrm{Mo}\left(\mathrm{L}^{\mathrm{Me}}\right)_{3}\right]$, the methyl-substituents impose less hindrance, and interconversion between different conformers can therefore occur on a faster timescale, leading to singleexponential MLCT decays. Related dynamic interconversions have been observed for some $\mathrm{Ru}(\mathrm{II})$ complexes. ${ }^{11}$

Going from toluene to THF, the MLCT lifetimes and luminescence quantum yields decrease in parallel in both complexes (Table 2). Qualitatively, this can be understood in the framework of the energy gap law, ${ }^{22}$ because the MLCT state is energetically stabilized in more polar THF (red-shifts observable in Figure 2c/d), leading to a smaller energy gap to the ground state and consequent faster nonradiative relaxation. Different propensities for energy dissipation via molecular vibrations of the various solvents could further contribute to the observable lifetime and quantum yield changes between $n$-hexane, toluene and THF. It is likely that the solvent nucleophilicity also plays a role with respect to the excited state lifetime, especially for $\left[\mathrm{Mo}\left(\mathrm{L}^{\mathrm{Me}}\right)_{3}\right]$, with more nucleophilic solvents more efficiently deactivating the excited state. However, nucleophilicity and energy-gap law effects are difficult to disentangle in low polarity solvents. The MLCT lifetimes of both complexes are strongly oxygen-sensitive, confirming the triplet nature of these excited states.

For the photoredox investigations below, the excitedstate oxidation potential $\left(\mathrm{E}_{\mathrm{ox}}{ }^{*}\right)$ is relevant, and this in turn requires knowledge of the energy of the photoactive ${ }^{3}$ MLCT state. Therefore, in addition to the emission experiments reported above, luminescence spectra were measured at $77 \mathrm{~K}$ (Figure $\mathrm{S}_{7}$ ) to estimate the energy of the electronic origin $\left(\mathrm{E}_{00}\right)$ of the ${ }^{3} \mathrm{MLCT}$ emission more accurately. This procedure yields an $\mathrm{E}_{00}$-value of $2.2 \mathrm{eV}$ for both complexes, leading to excited-state oxidation potentials of $\mathbf{- 2 . 2}$ and $\mathbf{- 2 . 3} \mathrm{V}$ vs SCE for $\left[\mathrm{Mo}\left(\mathrm{L}^{\mathrm{Me}}\right)_{3}\right]$ and $\left[\mathrm{Mo}\left(\mathrm{L}^{\mathrm{Bu}}\right)_{3}\right]$, respectively, as indicated in Figure 1c/d (gray shaded areas). Thus, both complexes should be far stronger photoreductants than isoelectronic $\left[\mathrm{Ru}(\mathrm{bpy})_{3}\right]^{2+}\left(\mathrm{E}_{\mathrm{ox}}{ }^{*}=-\right.$ 0.9 $\mathrm{V}$ vs SCE) and fac-$\left[\operatorname{Ir}(\mathrm{ppy})_{3}\right]\left(\mathrm{E}_{\mathrm{ox}}{ }^{*}=-1.73 \mathrm{~V}\right.$ vs SCE $){ }^{84}$

Scheme 2. Intramolecular base-promoted homolytic aromatic substitution (BHAS) via photoredox catalysis.

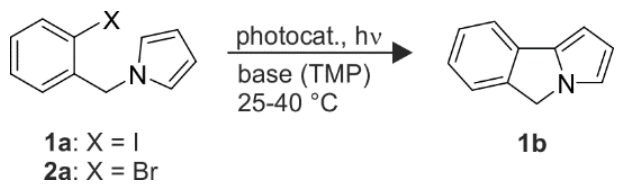

\section{Photochemical studies}

In our preliminary communication we reported that the $\left[\mathrm{Mo}\left(\mathrm{L}^{\mathrm{Me}}\right)_{3}\right]$ complex is able to photo-catalyze the rearrangement of an acyl-cyclopropane substrate to a 2,3dihydrofuran product, $3^{8}$ but we noticed that the presence of nucleophiles in the reaction mixture caused degradation of the Mo complex over time. We speculated that this degradation is caused by ligation of nucleophiles to the metal center in $\mathrm{Mo}(\mathrm{I})$ intermediates formed transiently in the course of the photocatalysis reaction cycle; sevencoordinate molybdenum isocyanide complexes are wellknown.93-94 We will now show that in the new $\left[\mathrm{Mo}\left(\mathrm{L}^{t \mathrm{Bu}}\right)_{3}\right]$ complex this problem no longer persists, presumably because the bulkier tert-butyl substituents more efficiently shield the metal from the chemical environment.

The main purpose of the studies below was to explore the photochemical properties of this new family of $\mathrm{d}^{6}$ MLCT emitters and to test their robustness in the presence of nucleophiles over extended irradiation times, rather than to develop new photoredox reactions. Towards this end, we concentrated on net redox-neutral cross-coupling between aryl halides and arenes, which can be considered 
electron-catalyzed reactions. ${ }^{39}$ A specific example is the intramolecular reaction between an aryl iodide and pyrrole (Scheme 2). Base-promoted homolytic aromatic substitution (BHAS) reactions of this type have been identified as a viable alternative to Pd- and Rh-based C-C bond formation, but they often require harsh conditions involving high temperatures and strong bases.95-100 Photochemical approaches to BHAS not relying on UV excitation have been relatively scarce so far..$^{101-106}$

Table 3. Performance of $\left[\mathrm{Mo}\left(\mathrm{L}^{\mathrm{Me}}\right)_{3}\right],\left[\mathrm{Mo}\left(\mathrm{L}^{\mathrm{tBu}}\right)_{3}\right]$, and fac- $\left[\operatorname{Ir}(\mathrm{ppy})_{3}\right]$ in the light-driven BHAS reaction of Scheme 2. ${ }^{a}$

\begin{tabular}{|c|c|c|c|c|}
\hline entry & substrate & complex & $\begin{array}{c}\text { irradiation } \\
\text { time } / \mathbf{h}\end{array}$ & $\begin{array}{c}\text { conversion } \\
/ \%\end{array}$ \\
\hline $\mathbf{1}$ & $\mathbf{1 a}$ & {$\left[\mathrm{Mo}\left(\mathrm{L}^{\mathrm{Me}}\right)_{3}\right]$} & $\mathbf{1}$ & 19 \\
\hline $\mathbf{2}$ & $\mathbf{1 a}$ & {$\left[\mathrm{Mo}\left(\mathrm{L}^{\mathrm{Me}}\right)_{3}\right]$} & 18 & 31 \\
\hline 3 & $\mathbf{1 a}$ & {$\left[\mathrm{Mo}\left(\mathrm{L}^{t \mathrm{Bu}}\right)_{3}\right]$} & $\mathbf{1}$ & 100 \\
\hline 4 & $\mathbf{1 a}$ & $\begin{array}{c}f a c- \\
{\left[\operatorname{Ir}(\mathrm{ppy})_{3}\right]}\end{array}$ & $\mathbf{1}$ & 4 \\
\hline 5 & $\mathbf{2 a}$ & {$\left[\mathrm{Mo}\left(\mathrm{L}^{t \mathrm{Bu}}\right)_{3}\right]$} & 18 & 7 \\
\hline
\end{tabular}

${ }^{a}$ Conditions: $50 \mathrm{mM}$ substrate, $5 \mathrm{~mol} \%$ metal complex, and 2 equivalents of 2,2,6,6-tetramethylpiperidine (TMP) in deaerated $\mathrm{C}_{6} \mathrm{D}_{6}$ at ca. $40^{\circ} \mathrm{C}$. Irradiation at $470 \mathrm{~nm}$ with $14 \mathrm{~W}$ LED. See Supporting Information pages S16-S19.

First, we tested the performance of the $\left[\mathrm{Mo}\left(\mathrm{L}^{\mathrm{Me}}\right)_{3}\right]$ complex as a photocatalyst for the reaction in Scheme 2, which can be conveniently followed by monitoring the benzylic ${ }^{1} \mathrm{H}$ NMR resonances of substrate and product (Figure $\mathrm{S}_{13}$ ). Using $50 \mathrm{mM}$ substrate $\mathbf{1 a}$ in de-aerated $\mathrm{C}_{6} \mathrm{D}_{6}$, 2 equivalents of 2,2,6,6-tetramethylpiperidine (TMP) as base, and a photocatalyst loading of $5 \mathrm{~mol} \%$ in a flamesealed NMR tube at room temperature, $19 \%$ of the substrate was converted to product $\mathbf{1 b}$ after irradiation at $470 \mathrm{~nm}$ with an LED (ca. $14 \mathrm{~W}$; see SI page S16 for details) for 1 hour (Table 3, entry 1). Maximum conversion of 31\% was observed after $18 \mathrm{~h}$ (Table 3, entry 2; Figure S13). Catalyst-based luminescence could not be detected after this time, implying decomposition of $\left[\mathrm{Mo}\left(\mathrm{L}^{\mathrm{Me}}\right)_{3}\right]$. The new $\left[\mathrm{Mo}\left(\mathrm{L}^{t \mathrm{Bu}}\right)_{3}\right]$ complex, however, catalyzed the reaction to completion within 1 hour (Table 3, entry 3; Figure s14). In comparison, use of $f a c-\left[\operatorname{Ir}(\mathrm{ppy})_{3}\right]\left(\mathrm{E}_{\mathrm{ox}}{ }^{*}=-1.73 \mathrm{~V}\right.$ vs SCE $)$ under identical conditions resulted in nearly negligible conversion over the same time period (Table 3, entry 4; Figure S15), and reactions did not reach conclusion even after over $100 \mathrm{~h}$ of continuous irradiation. As $\mathrm{fac}-\left[\operatorname{Ir}(\mathrm{ppy})_{3}\right]$ absorbs weakly at wavelengths longer than $450 \mathrm{~nm}$ and may therefore create a biased comparison, the experiments with $f a c$ - $\left[\operatorname{Ir}(\mathrm{ppy})_{3}\right]$ were repeated under $405 \mathrm{~nm}$ irradiation, which showed little difference to the results obtained with $470 \mathrm{~nm}$ irradiation (Figure S16).

The photochemical BHAS reaction is initiated by a reductive dehalogenation step (see below), and the promising results observed above for $\left[\mathrm{Mo}\left(\mathrm{L}^{t \mathrm{tBu}}\right)_{3}\right]$ encouraged us to explore the reaction of Scheme 2 with a bromo-substituted substrate (2a), which is more difficult to reduce than the iodo-arene of $\mathbf{1 a}$. However, only very modest conversion is observable and required extremely long irradiation times (Table 3, entry 5; Figure S17). Over the course of these experiments we found that the $\left[\mathrm{Mo}\left(\mathrm{L}^{t \mathrm{Bu}}\right)_{3}\right]$ complex still exhibited stable photoluminescence and was catalytically active after continuous irradiation exceeding two months.

Scheme 3. Proposed mechanism for the light-driven base-promoted homolytic aromatic substitution (BHAS) reaction of Scheme $2 .^{a}$

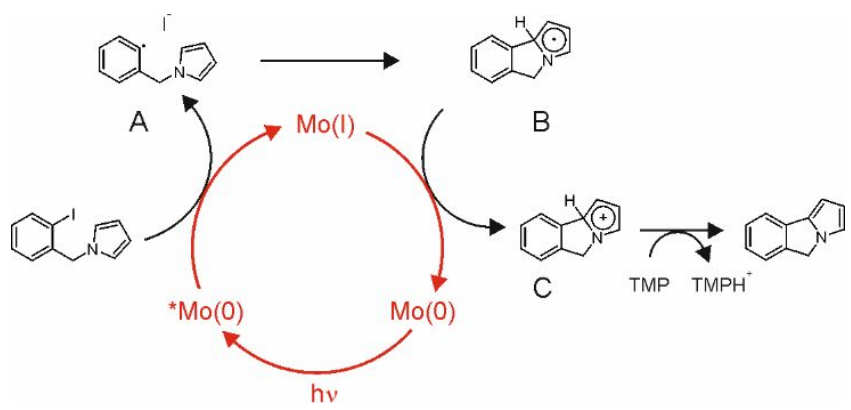

${ }^{a} \mathrm{Mo}(\mathrm{o}),{ }^{*} \mathrm{Mo}(\mathrm{o})$ and $\mathrm{Mo}(\mathrm{I})$ denote the $\left[\mathrm{Mo}\left(\mathrm{L}^{\mathrm{tBu}}\right)_{3}\right]$ complex in its initial ground state, its long-lived ${ }^{3 M L C T}$-excited state, and in its one-electron oxidized form, respectively. TMP is 2,2,6,6-tetramethylpiperidine.

A proposed mechanism for the photochemical BHAS reaction with $\left[\mathrm{Mo}\left(\mathrm{L}^{t \mathrm{Bu}}\right)_{3}\right]$ is presented in Scheme 3. Due to its high reducing power $\left(\mathrm{E}_{\text {ox }}{ }^{*}=-2.3 \mathrm{~V}\right.$ vs SCE, Figure $\left.1 \mathrm{~d}\right)$, the ${ }^{M}$ MLCT-excited Mo(o) complex is able to induce the initial reductive dehalogenation of iodobenzene substrate $1 \mathrm{a}\left(\mathrm{E}_{\mathrm{red}} \approx-\mathbf{2 . 2} \mathrm{eV}\right)^{107}$ in an efficient manner. In contrast, the photoexcited $f a c-\left[\operatorname{Ir}(\mathrm{ppy})_{3}\right]$ complex is substantially less reducing $\left(\mathrm{E}_{\mathrm{ox}}{ }^{*}=-1.73 \mathrm{~V}\right.$ vs $\left.\mathrm{SCE}\right),{ }^{84}$ and this is likely the main reason for its comparatively poor performance as a catalyst of the reaction in Scheme 2 (Table 3, entry 4). Bromobenzene has a reduction potential of ca. $-2.4 \mathrm{~V}$ vs SCE (in DMF), ${ }^{107}$ hence reductive dehalogenation of substrate 2a becomes inefficient even for photoexcited $\left[\mathrm{Mo}\left(\mathrm{L}^{\mathrm{tBu}}\right)_{3}\right]$ (Table 3, entry 5), especially in nonpolar $\mathrm{C}_{6} \mathrm{D}_{6}$. Photodriven reductive dehalogenation reactions are increasingly well investigated, ${ }^{108-111}$ and the general observation is that aryl bromides are substantially more difficult to reduce than aryl iodides, ${ }^{107,}, 12$ and aryl chlorides are even more challenging. ${ }^{106,113^{-115}}$ The liberation of $\mathrm{I}^{-}$in this initial step (and ligation of $\mathrm{I}^{-}$to $\mathrm{Mo}(\mathrm{I})$, see above) ${ }^{38}$ is likely responsible for the rather rapid degradation of $\left[\mathrm{Mo}\left(\mathrm{L}^{\mathrm{Me}}\right)_{3}\right]$ and the modest conversion achievable with this firstgeneration complex (Table 3, entries 1 \& 2). Aryl radicals usually have very short lifetimes, but in the specific case of aryl radical A (Scheme 3) intramolecular reaction with the radical interceptor pyrrole to form the cyclic intermediate $B$ is rather efficient. ${ }^{.16}$ Oxidation of intermediate $B$ by $\mathrm{Mo}(\mathrm{I})$ then re-instates the photosensitizer to its initial (electronic ground) state and leads to radical cation $\mathrm{C}$, which can be subsequently deprotonated to afford the final cyclization product. An important difference to thermal BHAS reactions is the presence of a weak base (TMP) rather than 
${ }^{t} \mathrm{BuOK}$, and it seems plausible that this renders deprotonation of intermediate $\mathrm{B}$ inefficient, making oxidation of $B$ to $C$ necessary before the proton can be abstracted by TMP. With ${ }^{t} \mathrm{BuOK}$ the reverse order of steps is commonly observed (deprotonation followed by oxidation), and this can give rise to a radical chain mechanism because the radical anion intermediate formed after the deprotonation step is strongly reducing (see Supporting Information page $\mathrm{S}_{15}$ for further details). ${ }^{100}$ In the mechanism of Scheme 3, the neutral radical intermediate $B$ is not sufficiently reducing to propagate a radical chain via electron donation to another equivalent of substrate.

Table 4. BHAS reactions to explore the photochemical reactivity of $\left[\mathrm{Mo}\left(\mathrm{L}^{t \mathrm{Bu}}\right)_{3}\right] .^{a}$

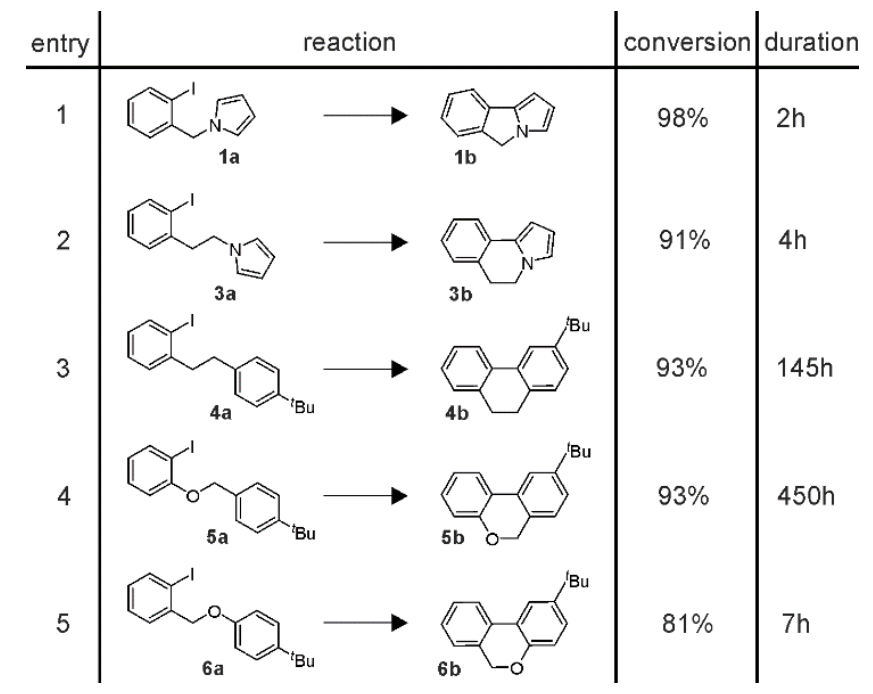

a Conditions were similar to those given in Table 3, but using a photo-reactor with active cooling to stabilize the temperature of the reaction mixture at $25^{\circ} \mathrm{C}$ throughout the complete irradiation process. See Supporting Information pages $\mathrm{S}_{16-S_{21}}$ for details.

To gain further insight into the photochemical performance of $\left[\mathrm{Mo}\left(\mathrm{L}^{t \mathrm{Bu}}\right)_{3}\right]$, we explored the carefully selected range of substrates in Table 4 , allowing us to probe the influence of structural and electronic variations on the light-driven BHAS reaction in systematic manner. Substrate $3 \mathbf{a}$ differs from $\mathbf{1 a}$ by the length of the alkyl linker, and the resulting increased conformational flexibility causes a need for longer reaction times (Table 4, entries 1 \& 2; Figure S19). Substrate 4a has the same ethylene linker as $3 a$, but the reaction time had to be lengthened further from $4 \mathrm{~h}$ to $145 \mathrm{~h}$ to reach a similar level of conversion (Table 4, entry 3; Figure S20). This can be attributed to the fact that tert-butylphenyl is a far less efficient interceptor for the aryl radical than pyrrole, ${ }^{116}$ rendering the step from A to B in Scheme 3 inefficient. Substrate 5a (Table 4, entry 4) has essentially the same linker length as $\mathbf{4 a}$, but one $\mathrm{CH}_{2}$ group has been replaced by an $\mathrm{O}$-atom. This makes the reaction even slower, now requiring $450 \mathrm{~h}$ instead of $145 \mathrm{~h}$ (Figure S21). The reason for this is likely the electron-donating nature of the alkoxy- linker, rendering the reduction potential of the iodobenzene unit more negative and making reductive deiodination in the initial reaction step more difficult. In substrate 6a (Table 4, entry 5) the alkoxy-linker is reversed compared to $\mathbf{5 a}$, with the O-atom connected to the tertbutylphenyl rather than the iodobenzene unit. This reduces the necessary reaction time to $7 \mathrm{~h}$ (for $81 \%$ conversion; Figure S22), likely because the electron donating nature of the alkoxy-linker now mostly acts on the tert-butylphenyl unit, making the deiodination of $\mathbf{6 a}$ less difficult and the oxidation step converting intermediate B to C (Scheme 3) more facile. The reactivities observable for the range of substrates $\mathbf{1 a}-\mathbf{6 a}$ thus seem compatible with the mechanism in Scheme 3. Evidently the $\left[\mathrm{Mo}\left(\mathrm{L}^{t \mathrm{Bu}}\right)_{3}\right]$ complex is much more robust in these photochemical experiments than $\left[\mathrm{Mo}\left(\mathrm{L}^{\mathrm{Me}}\right)_{3}\right]$, making the new tert-butylated complex far superior not just in terms of photophysical properties (see above) but also for photochemical applications involving challenging reduction steps not feasible with $\left[\mathrm{Ru}(\mathrm{bpy})_{3}\right]^{2+}$ or $\mathrm{fac}^{-}$ $\left[\operatorname{Ir}(\mathrm{ppy})_{3}\right]$.

\section{SUMMARY AND CONCLUSIONS}

Octahedrally coordinated low-spin $\mathrm{d}^{6}$ complexes made from precious metals such as $\mathrm{Ru}, \mathrm{Os}$, Re, or Ir have attracted interest for more than 40 years, yet to date only a handful of such complexes made from Earth-abundant metals are known to emit from MLCT excited states. ${ }^{117}$ Notably, the struggle to identify an MLCT-luminescent Fe(II) complex continues. ${ }^{11}$ The present study establishes Mo(o) complexes with chelating diisocyanide ligands as a new family of photoactive compounds that are structurally and electronically closely related to $\mathrm{Ru}(\mathrm{II})$ polypyridines. Their photophysical properties can be tuned through ligand modification to a point where their luminescence quantum yield surpasses that achievable for $\left[\mathrm{Ru}(\mathrm{bpy})_{3}\right]^{2+}$ by more than a factor of 2 . Shielding of the metal center from the chemical environment and rigidifying the complex by introducing steric congestion at the ligand periphery is the key to this favorable behavior. In this manner, it has been possible to reduce the rate for nonradiative excited-state decay by more than an order of magnitude between $\left[\mathrm{Mo}\left(\mathrm{L}^{\mathrm{Me}}\right)_{3}\right]$ and $\left[\mathrm{Mo}\left(\mathrm{L}^{t \mathrm{Bu}}\right)_{3}\right]$, leading to microsecond MLCT lifetimes and luminescence quantum yields as high as 0.203 . This design principle furthermore improved the photochemical robustness enormously, making the high reducing power of the ${ }^{3 \mathrm{MLCT}-e x c i t e d}$ $\left[\mathrm{Mo}\left(\mathrm{L}^{t \mathrm{Bu}}\right)_{3}\right]$ complex suitable for photochemical transformations that cannot be performed with the widely employed $\mathrm{fac}_{\mathrm{C}}\left[\operatorname{Ir}(\mathrm{ppy})_{3}\right]$ complex. Specifically, the inertness against nucleophilic attack at transiently oxidized Mo(I) metal centers seems of key importance, now permitting photoirradiation over very long periods (days to weeks) without significant complex degradation. A range of base-promoted homolytic aromatic substitution (BHAS) reactions with substrates specifically designed to underpin the photochemical mechanism was explored, demonstrating possibilities and limitations for application 
of the Mo(o) complexes for these overall redox-neutral reactions involving a thermodynamically challenging reductive dehalogenation and a $\mathrm{C}-\mathrm{H}$ activation step.

\section{ASSOCIATED CONTENT}

Supporting Information. Synthetic protocols, characterization data, additional spectroscopic data, details regarding photochemical experiments. This material is available free of charge via the Internet at http://pubs.acs.org.

\section{AUTHOR INFORMATION}

\section{Corresponding Author}

* oliver.wenger@unibas.ch

\section{Author Contributions}

The manuscript was written through contributions of all authors. All authors have given approval to the final version of the manuscript. ${ }^{\top}$ These authors contributed equally.

\section{Funding Sources}

Swiss National Science Foundation, grant number 200021_178760.

\section{ACKNOWLEDGMENT}

Funding from the Swiss National Science Foundation through grant number 200021_178760 is gratefully acknowledged.

\section{REFERENCES}

(1) Baldo, M. A.; Thompson, M. E.; Forrest, S. R., HighEfficiency Fluorescent Organic Light-Emitting Devices using a Phosphorescent Sensitizer. Nature 200o, 403, 750-753.

(2) Li, A.; Turro, C.; Kodanko, J. J., Ru(II) Polypyridyl Complexes Derived from Tetradentate Ancillary Ligands for Effective Photocaging. Acc. Chem. Res. 2018, 51, 1415-1421.

(3) Mari, C.; Pierroz, V.; Ferrari, S.; Gasser, G., Combination of Ru(II) Complexes and Light: New Frontiers in Cancer Therapy. Chem. Sci. 2015, 6, 2660-2686.

(4) Hagfeldt, A.; Grätzel, M., Molecular Photovoltaics. Acc. Chem. Res. 2000, 33, 269-277.

(5) Yoon, T. P.; Ischay, M. A.; Du, J. N., Visible Light Photocatalysis as a Greener Approach to Photochemical Synthesis. Nat. Chem. 2010, 2, 527-532.

(6) Gray, H. B.; Maverick, A. W., Solar Chemistry of MetalComplexes. Science 1981, 214, 1201-1205.

(7) McCusker, J. K., Electronic Structure in the Transition Metal Block and its Implications for Light Harvesting. Science 2019, 363, 484-488.

(8) Young, E. R.; Oldacre, A., Iron Hits the Mark. Science 2019, 363, 225-226.

(9) Liu, Y. Z.; Persson, P.; Sundström, V.; Wärnmark, K., Fe $\mathrm{N}$-Heterocyclic Carbene Complexes as Promising Photosensitizers. Acc. Chem. Res. 2016, 49, 1477-1485.

(10) Duchanois, T.; Liu, L.; Pastore, M.; Monari, A.; Cebrian, C.; Trolez, Y.; Darari, M.; Magra, K.; Frances-Monerris, A.; Domenichini, E.; Beley, M.; Assfeld, X.; Haacke, S.; Gros, P. C., NHC-Based Iron Sensitizers for DSSCs. Inorganics 2018, 6, 63, doi: 10.3390/inorganics6020063.

(11) Wenger, O. S., Is Iron the New Ruthenium? Chem. Eur. J. 2019, 25, 6043-6052.

(12) Steube, J.; Burkhardt, L.; Päpcke, A.; Moll, J.; Zimmer, P.; Schoch, R.; Wölper, C.; Heinze, K.; Lochbrunner, S.; Bauer, M.,
Excited-State Kinetics of an Air-Stable Cyclometalated Iron(II) Complex. Chem. Eur. J. 2019, doi: 10.1002/chem.201902488.

(13) Dixon, I. M.; Boissard, G.; Whyte, H.; Alary, F.; Heully, J. L., Computational Estimate of the Photophysical Capabilities of Four Series of Organometallic Iron(II) Complexes. Inorg. Chem. 2016, 55, 5089-5091.

(14) Ashley, D. C.; Jakubikova, E., Ironing out the Photochemical and Spin-Crossover Behavior of $\mathrm{Fe}(\mathrm{II})$ Coordination Compounds with Computational Chemistry. Coord. Chem. Rev. 2017, 337, 97-111.

(15) Zhang, W. K.; Gaffney, K. J., Mechanistic Studies of Photoinduced Spin Crossover and Electron Transfer in Inorganic Complexes. Acc. Chem. Res. 2015, 48, 1140-1148.

(16) Carey, M. C.; Adelman, S. L.; McCusker, J. K., Insights into the Excited State Dynamics of Fe(II) Polypyridyl Complexes from Variable-Temperature Ultrafast Spectroscopy. Chem. Sci. 2019, 10, 134-144.

(17) McCusker, J. K.; Walda, K. N.; Dunn, R. C.; Simon, J. D.; Magde, D.; Hendrickson, D. N., Subpicosecond ${ }^{1}$ MLCT-5T Intersystem Crossing of Low-Spin Polypyridyl Ferrous Complexes. J. Am. Chem. Soc. 1993, 115, 298-307.

(18) Auböck, G.; Chergui, M., Sub-5o-fs Photoinduced Spin Crossover in $\mathrm{Fe}\left(\mathrm{bpy}_{3}\right)^{2+}$. Nat. Chem. 2015, 7, 629-633.

(19) Jamula, L. L.; Brown, A. M.; Guo, D.; McCusker, J. K. Synthesis and Characterization of a High-Symmetry Ferrous Polypyridyl Complex: Approaching the $5 \mathrm{~T}_{2} / 3 \mathrm{~T}_{1}$ Crossing Point for $\mathrm{Fe}^{\mathrm{II}}$. Inorg. Chem. 2014, 53, 15-17.

(20) Shepard, S. G.; Fatur, S. M.; Rappe, A. K.; Damrauer, N. H., Highly Strained Iron(II) Polypyridines: Exploiting the Quintet Manifold To Extend the Lifetime of MLCT Excited States. J. Am. Chem. Soc. 2016, 138, 2949-2952.

(21) Fatur, S. M.; Shepard, S. G.; Higgins, R. F.; Shores, M. P.; Damrauer, N. H., A Synthetically Tunable System To Control MLCT Excited-State Lifetimes and Spin States in Iron(II) Polypyridines. J. Am. Chem. Soc. 2017, 139, 4493-4505.

(22) Mengel, A. K. C.; Förster, C.; Breivogel, A.; Mack, K.; Ochsmann, J. R.; Laquai, F.; Ksenofontov, V.; Heinze, K., A Heteroleptic Push-Pull Substituted Iron(II) Bis(tridentate) Complex with Low-Energy Charge-Transfer States. Chem.-Eur. J. 2015, 21, 704-714.

(23) Mengel, A. K. C.; Bissinger, C.; Dorn, M.; Back, O.; Förster, C.; Heinze, K., Boosting Vis/NIR Charge-Transfer Absorptions of Iron(II) Complexes by N-Alkylation and $\mathrm{N}$ Deprotonation in the Ligand Backbone. Chem.-Eur. J. 2017, 23, 7920-7931.

(24) Liu, Y. Z.; Harlang, T.; Canton, S. E.; Chabera, P.; SuarezAlcantara, K.; Fleckhaus, A.; Vithanage, D. A.; Goransson, E. Corani, A.; Lomoth, R.; Sundström, V.; Wärnmark, K., Towards Longer-Lived Metal-to-Ligand Charge Transfer States of Iron(II) Complexes: An N-Heterocyclic Carbene Approach. Chem. Commun. 2013, 49, 6412-6414.

(25) Harlang, T. C. B.; Liu, Y. Z.; Gordivska, O.; Fredin, L. A.; Ponseca, C. S.; Huang, P.; Chabera, P.; Kjaer, K. S.; Mateos, H.; Uhlig, J.; Lomoth, R.; Wallenberg, R.; Styring, S.; Persson, P.; Sundström, V.; Wärnmark, K., Iron Sensitizer Converts Light to Electrons with 92\% Yield. Nat. Chem. 2015, 7, 883-889.

(26) Liu, L.; Duchanois, T.; Etienne, T.; Monari, A.; Beley, M.; Assfeld, X.; Haacke, S.; Gros, P. C., A New Record Excited State 3MLCT Lifetime for Metalorganic Iron(II) Complexes. Phys. Chem. Chem. Phys. 2016, 18, 12550-12556.

(27) Duchanois, T.; Etienne, T.; Beley, M.; Assfeld, X.; Perpete, E. A.; Monari, A.; Gros, P. C., Heteroleptic PyridylCarbene Iron Complexes with Tuneable Electronic Properties. Eur. J. Inorg. Chem. 2014, 3747-3753.

(28) Liu, Y. Z.; Kjaer, K. S.; Fredin, L. A.; Chabera, P.; Harlang, T.; Canton, S. E.; Lidin, S.; Zhang, J. X.; Lomoth, R.; Bergquist, K. E.; Persson, P.; Wärnmark, K.; Sundström, V., A Heteroleptic 
Ferrous Complex with Mesoionic Bis(1,2,3-triazol-5-ylidene) Ligands: Taming the MLCT Excited State of Iron(II). Chem.-Eur. J. 2015, 21, 3628-3639.

(29) Chábera, P.; Liu, Y.; Prakash, O.; Thyrhaug, E.; El Nahhas, A.; Honarfar, A.; Essén, S.; Fredin, L. A.; Harlang, T. C. B.; Kjaer, K. S.; Handrup, K.; Ericsson, F.; Tatsuno, Y.; Morgan, K.; Schnadt, J.; Häggström, L.; Ericsson, T.; Sobkowiak, A.; Lidin, S.; Huang, P.; Styring, S.; Uhlig, J.; Bendix, J.; Lomoth, R.; Sundström, V.; Persson, P.; Wärnmark, K., A Low-Spin Fe(III) Complex with 100-ps Ligand-to-Metal Charge Transfer Photoluminescence. Nature 2017, 543, 695-699.

(30) Kjær, K. S.; Kaul, N.; Prakash, O.; Chábera, P.; Rosemann, N. W.; Honarfar, A.; Gordivska, O.; Fredin, L. A.; Bergquist, K. E.; Häggström, L.; Ericsson, T.; Lindh, L.; Yartsev, A.; Styring, S.; Huang, P.; Uhlig, J.; Bendix, J.; Strand, D.; Sundström, V.; Persson, P.; Lomoth, R.; K., W., Luminescence and Reactivity of a Charge-Transfer Excited Iron Complex with Nanosecond Lifetime. Science 2019, 363, 249-253.

(31) Chábera, P.; Kjaer, K. S.; Prakash, O.; Honarfar, A.; Liu, Y. Z.; Fredin, L. A.; Harlang, T. C. B.; Lidin, S.; Uhlig, J.; Sundström, V.; Lomoth, R.; Persson, P.; Wärnmark, K., Fe-II Hexa NHeterocyclic Carbene Complex with a 528 ps Metal-to-Ligand Charge-Transfer Excited-State Lifetime. J. Phys. Chem. Lett. 2018, 9, 459-463.

(32) Mann, K. R.; Cimolino, M.; Geoffroy, G. L.; Hammond, G. S.; Orio, A. A.; Albertin, G.; Gray, H. B., Electronic Structures and Spectra of Hexakisphenylisocyanide Complexes of $\mathrm{Cr}(\mathrm{o})$, Mo(o), W(o), Mn(I), and Mn(II). Inorg. Chim. Acta 1976, 16, 97101.

(33) Mann, K. R.; Gray, H. B.; Hammond, G. S., Excited-State Reactivity Patterns of Hexakisarylisocyano Complexes of Chromium(o), Molybdenum(o), and Tungsten(o). J. Am. Chem. Soc. 1977, 99, 306-307.

(34) Sattler, W.; Ener, M. E.; Blakemore, J. D.; Rachford, A. A.; LaBeaume, P. J.; Thackeray, J. W.; Cameron, J. F.; Winkler, J. R.; Gray, H. B., Generation of Powerful Tungsten Reductants by Visible Light Excitation. J. Am. Chem. Soc. 2o13, 135, 10614-10617.

(35) Sattler, W.; Henling, L. M.; Winkler, J. R.; Gray, H. B., Bespoke Photoreductants: Tungsten Arylisocyanides. J. Am. Chem. Soc. 2015, 137, 1198-1205.

(36) Büldt, L. A.; Wenger, O. S., Chromium(o), Molybdenum(o), and Tungsten(o) Isocyanide Complexes as Luminophores and Photosensitizers with Long-Lived Excited States. Angew. Chem. Int. Ed. 2017, 56, 5676-5682.

(37) Büldt, L. A.; Guo, X.; Vogel, R.; Prescimone, A.; Wenger, O. S., A Tris(diisocyanide)chromium(o) Complex Is a Luminescent Analog of $\mathrm{Fe}(2,2 \text { '-Bipyridine })_{3}^{2+}$. J. Am. Chem. Soc. 2017, 139, 985-992.

(38) Büldt, L. A.; Guo, X.; Prescimone, A.; Wenger, O. S., A Molybdenum(o) Isocyanide Analogue of $\mathrm{Ru}(2,2 \text {-Bipyridine })_{3}{ }^{2+}: \mathrm{A}$ Strong Reductant for Photoredox Catalysis. Angew. Chem. Int. Ed. 2016, 55, 11247-11250.

(39) Studer, A.; Curran, D. P., The Electron is a Catalyst. Nature Chem. 2014, 6, 765-773.

(40) Hamze, R.; Peltier, J. L.; Sylvinson, D.; Jung, M.; Cardenas, J.; Haiges, R.; Soleilhavoup, M.; Jazzar, R.; Djurovich, P. I.; Bertrand, G.; Thompson, M. E., Eliminating Nonradiative Decay in $\mathrm{Cu}(\mathrm{I})$ Emitters: $>99 \%$ Quantum Efficiency and Microsecond Lifetime. Science 2019, 363, 601-606.

(41) Gernert, M.; Müller, U.; Haehnel, M.; Pflaum, J.; Steffen, A., A CyclicAlkyl(amino)carbene as Two-Atom $\pi$-Chromophore Leading to the First Phosphorescent Linear $\mathrm{Cu}^{\mathrm{I}}$ Complexes. Chem. Eur. J. 2017, 23, 2206-2216.

(42) Di, D. W.; Romanov, A. S.; Yang, L.; Richter, J. M.; Rivett, J. P. H.; Jones, S.; Thomas, T. H.; Jalebi, M. A.; Friend, R. H.; Linnolahti, M.; Bochmann, M.; Credgington, D., High-
Performance Light-Emitting Diodes based on Carbene-MetalAmides. Science 2017, 356, 159-163.

(43) Leoni, E.; Mohanraj, J.; Holler, M.; Mohankumar, M.; Nierengarten, I.; Monti, F.; Sournia-Saquet, A.; Delavaux-Nicot, B.; Nierengarten, J. F.; Armaroli, N., Heteroleptic Copper(I) Complexes Prepared from Phenanthroline and Bis-Phosphine Ligands: Rationalization of the Photophysical and Electrochemical Properties. Inorg. Chem. 2018, 57, 15537-15549.

(44) Hossain, A.; Bhattacharyya, A.; Reiser, O., Copper's Rapid Ascent in Visible-Light Photoredox Catalysis. Science 2019, 364, doi: 10.1126/science.aav9713.

(45) Hernandez-Perez, A. C.; Collins, S. K., Heteroleptic CuBased Sensitizers in Photoredox Catalysis. Acc. Chem. Res. 2016, 49, 1557-1565.

(46) Michelet, B.; Deldaele, C.; Kajouj, S.; Moucheron, C.; Evano, G., A General Copper Catalyst for Photoredox Transformations of Organic Halides. Org. Lett. 2017, 19, 35763579 .

(47) Nicholls, T. P.; Caporale, C.; Massi, M.; Gardiner, M. G.; Bissember, A. C., Synthesis and Characterisation of Homoleptic 2,9-Diaryl-1,10-Phenanthroline Copper(I) Complexes: Influencing Selectivity in Photoredox-Catalysed Atom-Transfer Radical Addition Reactions. Dalton Trans. 2019, 48, 7290-7301.

(48) Lazorski, M. S.; Castellano, F. N., Advances in the Light Conversion Properties of $\mathrm{Cu}(\mathrm{I})$-Based Photosensitizers. Polyhedron 2014, 82, 57-70.

(49) Czerwieniec, R.; Leitl, M. J.; Homeier, H. H. H.; Yersin, $\mathrm{H}$., $\mathrm{Cu}(\mathrm{I})$ Complexes - Thermally Activated Delayed Fluorescence. Photophysical Approach and Material Design. Coord. Chem. Rev. 2016, 325, 2-28.

(50) Mondal, R.; Lozada, I. B.; Davis, R. L.; Williams, J. A. G.; Herbert, D. E., Exploiting Synergy Between Ligand Design and Counterion Interactions to Boost Room Temperature Phosphorescence from $\mathrm{Cu}(\mathrm{I})$ Compounds. J. Mater. Chem. C 2019, 7, 3772-3778.

(51) Wang, C.; Otto, S.; Dorn, M.; Kreidt, E.; Lebon, J.; Srsan, L.; Di Martino-Fumo, P.; Gerhards, M.; Resch-Genger, U.; Seitz, M.; Heinze, K., Deuterated Molecular Ruby with Record Luminescence Quantum Yield. Angew. Chem. Int. Ed. 2018, 57, 1112-1116.

(52) Jimenez, J. R.; Doistau, B.; Besnard, C.; Piguet, C., Versatile Heteroleptic Bis-Terdentate $\mathrm{Cr}(\mathrm{III})$ Chromophores Displaying Room Temperature Millisecond Excited State Lifetimes. Chem. Commun. 2018, 54, 13228-13231.

(53) Stevenson, S. M.; Shores, M. P.; Ferreira, E. M., Photooxidizing Chromium Catalysts for Promoting Radical Cation Cycloadditions. Angew. Chem. Int. Ed. 2015, 54, 6506-6510.

(54) Ford, P. C., Metal Complex Strategies for PhotoUncaging the Small Molecule Bioregulators Nitric Oxide and Carbon Monoxide. Coord. Chem. Rev. 2o18, 376, 548-564.

(55) Pal, A. K.; Li, C. F.; Hanan, G. S.; Zysman-Colman, E., Blue-Emissive Cobalt(III) Complexes and Their Use in the Photocatalytic Trifluoromethylation of Polycyclic Aromatic Hydrocarbons. Angew. Chem. Int. Ed. 2018, 57, 8027-8031.

(56) Welin, E. R.; Le, C.; Arias-Rotondo, D. M.; McCusker, J. K.; MacMillan, D. W. C., Photosensitized, Energy TransferMediated Organometallic Catalysis through Electronically Excited Nickel(II). Science 2017, 355, 380-384.

(57) Shields, B. J.; Kudisch, B.; Scholes, G. D.; Doyle, A. G., Long-Lived Charge-Transfer States of Nickel(II) Aryl Halide Complexes Facilitate Bimolecular Photoinduced Electron Transfer. J. Am. Chem. Soc. 2018, 140, 3035-3039.

(58) Grübel, M.; Bosque, I.; Altmann, P. J.; Bach, T.; Hess, C. R., Redox and Photocatalytic Properties of a Ni ${ }^{\mathrm{II}}$ Complex with a Macrocyclic Biquinazoline (Mabiq) Ligand. Chem. Sci. 2018, 9, 3313-3317. 
(59) Zhang, Y.; Lee, T. S.; Petersen, J. L.; Milsmann, C., A Zirconium Photosensitizer with a Long-Lived Excited State: Mechanistic Insight into Photoinduced Single-Electron Transfer. J. Am. Chem. Soc. 2018, 140, 5934-5947.

(6o) Zhang, Y.; Petersen, J. L.; Milsmann, C., Photochemical C-C Bond Formation in Luminescent Zirconium Complexes with CNN Pincer Ligands. Organometallics 2018, 37, 4488-4499.

(61) Yeung, K. T.; To, W. P.; Sun, C. Y.; Cheng, G.; Ma, C. S.; Tong, G. S. M.; Yang, C.; Che, C. M., Luminescent Tungsten(VI) Complexes: Photophysics and Applicability to Organic LightEmitting Diodes and Photocatalysis. Angew. Chem. Int. Ed. 2017, 56, 133-137.

(62) Rudshteyn, B.; Vibbert, H. B.; May, R.; Wasserman, E.; Warnke, I.; Hopkins, M. D.; Batista, V. S., Thermodynamic and Structural Factors That Influence the Redox Potentials of Tungsten-Alkylidyne Complexes. ACS Catal. 2017, 7, 6134-6143.

(63) Kvapilova, H.; Sattler, W.; Sattler, A.; Sazanovich, I. V.; Clark, I. P.; Towrie, M.; Gray, H. B.; Zalis, S.; Vlcek, A., Electronic Excited States of Tungsten(o) Arylisocyanides. Inorg. Chem. 2015, $54,8518-8528$.

(64) Qiao, Y. S.; Schelter, E. J., Lanthanide Photocatalysis. Acc. Chem. Res. 2018, 51, 2926-2936.

(65) Romero, N. A.; Nicewicz, D. A., Organic Photoredox Catalysis. Chem. Rev. 2016, 116, 10075-10166.

(66) Ghosh, I.; Marzo, L.; Das, A.; Shaikh, R.; König, B., Visible Light Mediated Photoredox Catalytic Arylation Reactions. Acc. Chem. Res. 2016, 49, 1566-1577.

(67) Speckmeier, E.; Fischer, T. G.; Zeitler, K., A Toolbox Approach to Construct Broadly Applicable Metal-Free Catalysts for Photoredox Chemistry: Deliberate Tuning of Redox Potentials and Importance of Halogens in Donor-Acceptor Cyanoarenes. J. Am. Chem. Soc. 2018, 140, 15353-15365.

(68) Fischer, C.; Sparr, C., Direct Transformation of Esters into Heterocyclic Fluorophores. Angew. Chem. Int. Ed. 2018, 57, 2436-2440.

(69) McCarthy, B. G.; Pearson, R. M.; Lim, C. H.; Sartor, S. M.; Damrauer, N. H.; Miyake, G. M., Structure-Property Relationships for Tailoring Phenoxazines as Reducing Photoredox Catalysts. J. Am. Chem. Soc. 2018, 140, 5088-5101.

(7o) Drance, M. J.; Sears, J. D.; Mrse, A. M.; Moore, C. E.; Rheingold, A. L.; Neidig, M. L.; Figueroa, J. S., Terminal Coordination of Diatomic Boron Monofluoride to Iron. Science 2019, 363, 1203-1205.

(71) Margulieux, G. W.; Weidemann, N.; Lacy, D. C.; Moore, C. E.; Rheingold, A. L.; Figueroa, J. S., Isocyano Analogues of $\mathrm{Co}(\mathrm{CO})_{4}{ }^{\mathrm{n}}$ : A Tetraisocyanide of Cobalt Isolated in Three States of Charge. J. Am. Chem. Soc. 2010, 132, 5033-5035.

(72) Angelici, R. J.; Quick, M. H.; Kraus, G. A.; Plummer, D. T., Synthesis of Chelating Bidentate Isocyano and Cyano Ligands and Their Metal Complexes. Inorg. Chem. 1982, 21, 2178-2184.

(73) Plummer, D. T.; Angelici, R. J., Synthesis and Characterization of Homoleptic Complexes of the Chelating Bidentate Isocyano Ligand tert-BuDiNC. Inorg. Chem. 1983, 22, 4063-4070.

(74) Plummer, D. T.; Kraus, G. A.; Angelici, R. J., Synthesis of Chelating Bidentate and Tridentate Cyano Ligands and their Complexes with Group 7 Metal Carbonyls. Inorg. Chem. 1983, 22, 3492-3497.

(75) Hahn, F. E.; Tamm, M., Chelate Complexes with Triisocyanide Ligands. Angew. Chem. Int. Ed. 1991, 30, 203-205.

(76) Hahn, F. E., The Coordination Chemistry of Multidentate Isocyanide Ligands. Angew. Chem. Int. Ed. 1993, 32, $650-665$.

(77) Naik, A.; Maji, T.; Reiser, O., Iron(II)-Bis(isonitrile) Complexes: Novel Catalysts in Asymmetric Transfer Hydrogenations of Aromatic and Heteroaromatic Ketones. Chem. Commun. 2010, 46, 4475-4477.
(78) Vicenzi, D.; Sgarbossa, P.; Biffis, A.; Tubaro, C.; Basato, M.; Michelin, R. A.; Lanza, A.; Nestola, F.; Bogialli, S.; Pastore, P.; Venzo, A., Platinum(II) Complexes with Novel Diisocyanide Ligands: Catalysts in Alkyne Hydroarylation. Organometallics 2013, 32, 7153-7162.

(79) Monti, F.; Baschieri, A.; Matteucci, E.; Mazzanti, A.; Sambri, L.; Barbieri, A.; Armaroli, N., A Chelating Diisocyanide Ligand for Cyclometalated Ir(III) Complexes with Strong and Tunable Luminescence. Faraday Discuss. 2015, 185, 233-248.

(8o) Knorn, M.; Rawner, T.; Czerwieniec, R.; Reiser, O., Copper(phenanthroline)(bisisonitrile)+-Complexes for the Visible-Light-Mediated Atom Transfer Radical Addition and Allylation Reactions. ACS Catal. 2015, 5, 5186-5193.

(81) Emerich, B. M.; Moore, C. E.; Fox, B. J.; Rheingold, A. L.; Figueroa, J. S., Protecting-Group-Free Access to a ThreeCoordinate Nickel(o) Tris-isocyanide. Organometallics 2011, 30, 2598-2608.

(82) Cotton, F. A.; Zingales, F., Donor-Acceptor Properties of Isonitriles as Estimated by Infrared Study. J. Am. Chem. Soc. 1961, $83,351-355$.

(83) Bohling, D. A.; Mann, K. R.; Enger, S.; Gennett, T.; Weaver, M. J.; Walton, R. A., Electrochemical Redox Behavior of the Hexakis(arylisocyanide) Complexes of Molybdenum(o) and Tungsten(o). Inorg. Chim. Acta 1985, 97, L51-L53.

(84) Arias-Rotondo, D. M.; McCusker, J. K., The Photophysics of Photoredox Catalysis: A Roadmap for Catalyst Design. Chem. Soc. Rev. 2o16, 45, 5803-5820.

(85) Bohling, D. A.; Evans, J. F.; Mann, K. R., Inductive, Steric, and Environmental Effects in the Non-Aqueous Electrochemistry of Hexakis(Aryl Isocyanide) Chromium Complexes. Inorg. Chem. 1982, 21, 3546-3551.

(86) Suzuki, K.; Kobayashi, A.; Kaneko, S.; Takehira, K.; Yoshihara, T.; Ishida, H.; Shiina, Y.; Oishic, S.; Tobita, S., Reevaluation of Absolute Luminescence Quantum Yields of Standard Solutions Using a Spectrometer with an Integrating Sphere and a Back-Thinned CCD Detector. Phys. Chem. Chem. Phys. 2009, 11, 9850-986o.

(87) Cuttell, D. G.; Kuang, S. M.; Fanwick, P. E.; McMillin, D. R.; Walton, R. A., Simple Cu(I) Complexes with Unprecedented Excited-State Lifetimes. J. Am. Chem. Soc. 2002, 124, 6-7.

(88) Brunner, F.; Babaei, A.; Pertegas, A.; JunqueraHernandez, J. M.; Prescimone, A.; Constable, E. C.; Bolink, H. J.; Sessolo, M.; Orti, E.; Housecroft, C. E., Phosphane Tuning in Heteroleptic $\mathrm{Cu}\left(\mathrm{N}^{\wedge} \mathrm{N}\right)\left(\mathrm{P}^{\wedge} \mathrm{P}\right)^{+}$Complexes for Light-Emitting Electrochemical Cells. Dalton Trans. 2019, 48, 446-46o.

(89) Armaroli, N., Photoactive Mono- and Polynuclear $\mathrm{Cu}(\mathrm{I})$-Phenanthrolines. A Viable Alternative to $\mathrm{Ru}(\mathrm{II})$ Polypyridines? Chem. Soc. Rev. 2001, 30, 113-124.

(9o) Yoshimura, A.; Hoffman, M. Z.; Sun, H., An Evaluation of the Excited-State Absorption-Spectrum of $\mathrm{Ru}(\mathrm{bpy})_{3}{ }_{3}^{2+}$ in Aqueous and Acetonitrile Solutions. J. Photochem. Photobiol. A 1993, 70, 29-33.

(91) Jarenmark, M.; Carlström, G.; Fredin, L. A.; Wallenstein, J. H.; Doverbratt, I.; Abrahamsson, M.; Persson, P., Diastereomerization Dynamics of a Bistridentate Ru-II Complex. Inorg. Chem. 2016, 55, 3015-3022.

(92) Caspar, J. V.; Meyer, T. J., Application of the Energy-Gap Law to Nonradiative Excited-State Decay. J. Phys. Chem. 1983, 87, 952-957.

(93) Klendworth, D. D.; Welters, W. W.; Walton, R. A., Redox Chemistry of Hexakis(Phenyl Isocyanide) Complexes of Molybdenum and Tungsten - The Synthesis of the 7 -Coordinate Cations $\left[\mathrm{M}(\mathrm{CNPh})_{7}\right]^{2+}$ and their Electrochemistry and Substitution Reactions. Organometallics 1982, 1, 336-343.

(94) Caravana, C.; Giandomenico, C. M.; Lippard, S. J., Electrochemical Studies of 7-Coordinate Isocyanide Complexes of 
Molybdenum(II) and Tungsten(II). Inorg. Chem. 1982, 21, 186o1863.

(95) Yanagisawa, S.; Ueda, K.; Taniguchi, T.; Itami, K., Potassium $t$-Butoxide Alone Can Promote the Biaryl Coupling of Electron-Deficient Nitrogen Heterocycles and Haloarenes. Org. Lett. 2008, 10, 4673-4676.

(96) Studer, A.; Curran, D. P., Organocatalysis and C-H Activation Meet Radical- and Electron-Transfer Reactions. Angew. Chem. Int. Ed. 2011, 50, 5018-5022.

(97) Liu, W.; Cao, H.; Zhang, H.; Chung, K. H.; He, C. A.; Wang, H. B.; Kwong, F. Y.; Lei, A. W., Organocatalysis in CrossCoupling: DMEDA-Catalyzed Direct $\mathrm{C}-\mathrm{H}$ Arylation of Unactivated Benzene. J. Am. Chem. Soc. 2010, 132, 16737-16740.

(98) Sun, C. L.; Li, H.; Yu, D. G.; Yu, M. A.; Zhou, X. A.; Lu, X. Y.; Huang, K.; Zheng, S. F.; Li, B. J.; Shi, Z. J., An Efficient Organocatalytic Method for Constructing Biaryls through Aromatic C-H Activation. Nature Chem. 2010, 2, 1044-1049.

(99) Shirakawa, E.; Itoh, K.; Higashino, T.; Hayashi, T., tertButoxide-Mediated Arylation of Benzene with Aryl Halides in the Presence of a Catalytic 1,10-Phenanthroline Derivative. J. Am. Chem. Soc. 2010, 132, 15537-15539.

(10o) Zhang, L.; Yang, H.; Jiao, L., Revisiting the Radical Initiation Mechanism of the Diamine-Promoted TransitionMetal-Free Cross-Coupling Reaction. J. Am. Chem. Soc. 2016, 138, 7151-7160.

(101) Buden, M. E.; Guastavino, J. F.; Rossi, R. A., RoomTemperature Photoinduced Direct C-H-Arylation via BasePromoted Homolytic Aromatic Substitution. Org. Lett. 2013, 15, 1174-1177.

(102) Zheng, X. L.; Yang, L.; Du, W. Y.; Ding, A. S.; Guo, H., Amine-Catalyzed Direct Photoarylation of Unactivated Arenes. Chem.-Asian J. 2014, 9, 439-442.

(103) Kawamoto, T.; Sato, A.; Ryu, I., CyanoborohydridePromoted Radical Arylation of Benzene. Org. Lett. 2014, 16, 21112113.

(104) Cheng, Y. N.; Gu, X. Y.; Li, P. X., Visible-Light Photoredox in Homolytic Aromatic Substitution: Direct Arylation of Arenes with Aryl Halides. Org. Lett. 2013, 15, 2664-2667.

(105) Xu, Z.; Gao, L.; Wang, L. L.; Gong, M. W.; Wang, W. F.; Yuan, R. S., Visible Light Photoredox Catalyzed Biaryl Synthesis Using Nitrogen Heterocycles as Promoter. ACS Catal. 2015, 5, 4550.

(106) Ghosh, I.; Ghosh, T.; Bardagi, J. I.; König, B., Reduction of Aryl Halides by Consecutive Visible Light-Induced Electron Transfer Processes. Science 2014, 346, 725-728.
(107) Pause, L.; Robert, M.; Savéant, J. M., Can Single-Electron Transfer Break an Aromatic Carbon-Heteroatom Bond in One Step? A Novel Example of Transition between Stepwise and Concerted Mechanisms in the Reduction of Aromatic Iodides. J. Am. Chem. Soc. 1999, 121, 7158-7159.

(108) Nguyen, J. D.; D'Amato, E. M.; Narayanam, J. M. R.; Stephenson, C. R. J., Engaging Unactivated Alkyl, Alkenyl and Aryl Iodides in Visible-Light-Mediated Free Radical Reactions. Nat. Chem. 2012, 4, 854-859.

(109) Poelma, S. O.; Burnett, G. L.; Discekici, E. H.; Mattson, K. M.; Treat, N. J.; Luo, Y. D.; Hudson, Z. M.; Shankel, S. L.; Clark, P. G.; Kramer, J. W.; Hawker, C. J.; de Alaniz, J. R., Chemoselective Radical Dehalogenation and C-C Bond Formation on Aryl Halide Substrates Using Organic Photoredox Catalysts. J. Org. Chem. 2016, 81, 7155-716o.

(110) Kim, H.; Lee, C., Visible-Light-Induced Photocatalytic Reductive Transformations of Organohalides. Angew. Chem. Int. Ed. 2012, 51, 12303-12306.

(111) Shon, J.-H.; Sittel, S.; Teets, T. S., Synthesis and Characterization of Strong Cyclometalating Iridium Photoreductants for Application in Photocatalytic Aryl Bromide Hydrodebromination. ACS Catal. 2019, doi: 10.1021/acscatal.9bo2759.

(112) Devery, J. J.; Nguyen, J. D.; Dai, C. H.; Stephenson, C. R. J., Light-Mediated Reductive Debromination of Unactivated Alkyl and Aryl Bromides. ACS Catal. 2o16, 6, 5962-5967.

(113) Yin, H. L.; Carroll, P. J.; Manor, B. C.; Anna, J. M.; Schelter, E. J., Cerium Photosensitizers: Structure-Function Relationships and Applications in Photocatalytic Aryl Coupling Reactions. J. Am. Chem. Soc. 2016, 138, 5984-5993.

(114) Ghosh, I.; König, B., Chromoselective Photocatalysis: Controlled Bond Activation through Light-Color Regulation of Redox Potentials. Angew. Chem. Int. Ed. 2016, 55, 7676-7679.

(115) Neumeier, M.; Sampedro, D.; Májek, M.; de la Peña O'Shea, V. A.; Jacobi von Wangelin, A.; Pérez-Ruiz, R., Dichromatic Photocatalytic Substitutions of Aryl Halides with a Small Organic Dye. Chem. Eur. J. 2018, 24, 105-108.

(116) Gritter, R. J.; Chriss, R. J., Free-Radical Reactions of Pyrroles. J. Org. Chem. 1964, 29, 1163-1167.

(117) Wenger, O. S., Photoactive Complexes with EarthAbundant Metals. J. Am. Chem. Soc. 2018, 140, 13522-13533.

\section{Table of Contents artwork}

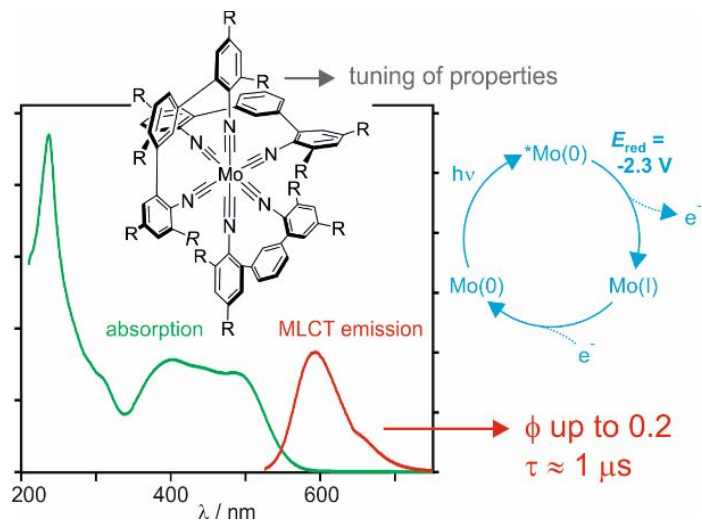

